УДК 378.016:796]:796.421

DOI https://doi.org/10.26661/2663-5925-2021-2-02

\title{
УПРОВАДЖЕННЯ СКАНДИНАВСЬКОЇ ХОДЬБИ В СИСТЕМУ ФІЗИЧНОГО ВИХОВАННЯ СТУДЕНТІВ
}

\author{
Баканова О. Ф. \\ кандидат із фізичного виховання і спорту, дочент, \\ завідувач кафедри фізичного виховання, спорту та здоров'я \\ Національний аерокосмічний університет імені М. С. Жуковського \\ «Харківський авіаційний інститут» \\ вул. Чкалова, 17, Харків, Україна \\ orcid.org/0000-0002-9642-5198 \\ alextenn@ukr.net \\ Самохін О. О. \\ старший викладач кафедри фізичного виховання, спорту та здоров'я \\ Начіональний аерокосмічний університет імені М. С. Жуковського

$$
\begin{gathered}
\text { «Харківський авіаиійний інститут» } \\
\text { вул. Чкалова, 17, Харків, Украӥна } \\
\text { orcid.org/0000-0002-0752-4013 } \\
\text { Samokhin.aleksej@gmail.com }
\end{gathered}
$$ \\ Криворучко С. М. \\ старший викладач кафедри фізичного виховання, спорту та здоров'я \\ Національний аерокосмічний університет імені М. С. Жуковського \\ «Харківський авіаційний інститут» \\ вул. Чкалова, 17, Харків, Україна \\ orcid.org/0000-0002-6189-6045 \\ Kraja.svetlana@gmail.com
}

\section{Крамаренко В. I.}

старший викладач кафедри фізичного виховання, спорту та здоров'я Національний аерокосмічний університет імені М. С. Жуковського

$$
\begin{gathered}
\text { «Харківський авіаційний інститут» } \\
\text { вул. Чкалова, 17, Харків, Украӥна } \\
\text { orcid.org/0000-0002-7086-3499 } \\
\text { Limonlion@gmail.com }
\end{gathered}
$$

\footnotetext{
Ключові слова:

скандинавська ходьба, фізичне виховання, студенти, навчальновиховний прочес.
}

У статті розглядається ефективність упровадження скандинавської ходьби в систему навчально-виховного процесу з фізичного виховання студентів. Результати дослідження засвідчили, що скандинавська ходьба за своєю фізіологічною дією на організм належить до ефективних циклічних вправ аеробного спрямування і може використовуватись як для збільшення обсягу рухової активності, так і для корекції чинників ризику розвитку серцево-судинних захворювань, поліпшення функції дихання і кровообігу, опорно-рухового апарату, обміну речовин. Аналіз сучасного стану фізкультурно-оздоровчої роботи в закладах вищої освіти свідчить, що скандинавська ходьба має великий потенціал, оскільки може бути представлена в системі навчально-виховного процесу з фізичного виховання як засіб загальної фізичної підготовки 
студентів, позанавчальної форми організації занять та окремий самостійний спецкурс. Мета дослідження полягає в розкритті ролі i значення скандинавської ходьби в організації самостійних занять студентів як одного із чинників покращення здорового способу життя. Методи дослідження: теоретичний аналіз і узагальнення літературних джерел (проведено пошук інформації та з'ясовано обгрунтованість наукової проблематики дослідження), методи математичної статистики. Результати дослідження. Проаналізовано сучасні дослідження з питань ефективності впровадження засобів скандинавської ходьби в навчальновиховний процес із фізичного виховання студентської молоді. Розкрито роль і значення скандинавської ходьби під час організації самостійних занять студентів як одного із чинників покращення здорового способу життя. Встановлено, що впровадження скандинавської ходьби в навчально-виховний процес із фізичного виховання позитивно впливає на формування у студентів мотивації та інтересу до занять цим видом спорту, що виявляється у ставленні їх до занять із фізичного виховання та до самостійних занять фізичними вправами. Висновки. Результати дослідження засвідчили, що скандинавська ходьба за своєю фізіологічною дією на організм належить до ефективних циклічних вправ аеробного спрямування і може використовуватись як для збільшення обсягу рухової активності, так і для корекції чинників ризику розвитку серцево-судинних захворювань, поліпшення функції дихання і кровообігу, опорно-рухового апарату, обміну речовин. Доведено, що впровадження скандинавської ходьби в навчально-виховний процес із фізичного виховання позитивно впливає на формування у студентів мотивації та інтересу до занять скандинавською ходьбою, ставлення їх до занять із фізичного виховання, самостійних занять фізичними вправами.

\title{
INTRODUCTION OF NORDIC WALKING INTO THE SYSTEM OF PHYSICAL EDUCATION OF STUDENTS
}

\author{
Bakanova O. F. \\ Ph.D. in Physical Education and Sports, Associate Professor, \\ Head of the Department of Physical Education, Sports and Health \\ National Aerospace University "Kharkiv Aviation Institute" \\ Chkalova str., 17, Kharkiv, Ukraine \\ orcid.org/0000-0002-9642-5198 \\ alextenn@ukr.net \\ Samokhin O. O. \\ Senior Lecturer at the Department of Physical Education, Sports and Health \\ National Aerospace University "Kharkiv Aviation Institute" \\ Chkalova str., 17, Kharkiv, Ukraine \\ orcid.org/0000-0002-0752-4013 \\ Samokhin.aleksej@gmail.com \\ Kryvoruchko S. M. \\ Senior Lecturer at the Department of Physical Education, Sports and Health \\ National Aerospace University "Kharkiv Aviation Institute" \\ Chkalova str., 17, Kharkiv, Ukraine \\ orcid.org/0000-0002-6189-6045 \\ Kraja.svetlana@gmail.com
}




\section{Kramarenko V. I. \\ Senior Lecturer at the Department of Physical Education, Sports and Health National Aerospace University "Kharkiv Aviation Institute" \\ Chkalova str., 17, Kharkiv, Ukraine \\ orcid.org/0000-0002-7086-3499 \\ Limonlion@gmail.com}

Key words: nordic walking, physical education, students, educational process.
The article considers the effectiveness of the introduction of Nordic walking in the system of educational process of physical education of students. The results of the study have shown that Nordic walking in its physiological effect on the body is an effective cyclic exercise of aerobic direction and can be used to increase motor activity and to correct risk factors for cardiovascular disease, improve respiratory and circulatory function, support of musculoskeletal system, metabolism. Analysis of the current state of physical culture and health work in higher education shows that Nordic walking has great potential, as it can be represented in the educational process of physical education as a mean of general physical training of students, in extracurricular activities and as a separate special course. The goal of the research is to reveal the role and importance of Nordic walking in the organization of self-study of students as one of the factors of improving a healthy lifestyle. Research methods: theoretical analysis and generalization of literary sources (search of information and clarification of scientific problems of the research; methods of mathematical statistics. Research results. Modern research on the effectiveness of the introduction of Nordic walking in the educational process of physical education of student youth is analyzed. The role and significance of Nordic walking in the organization of self-study of students as one of the factors of improving a healthy lifestyle is revealed. It is established that the introduction of Nordic walking in the educational process of physical education has a positive effect on the formation of students' motivation and interest in this sport, which is manifested in their attitude to physical education and to self-study. Conclusions. The results of the research have shown that Nordic walking in its physiological effect on the body is an effective cyclic exercise of aerobic direction and can be used to increase physical activity and to correct risk factors for cardiovascular disease, improve respiratory and circulatory function, musculoskeletal system, metabolism. It has been proved that the introduction of Nordic walking in the educational process of physical education has a positive effect on the formation of student' motivation and interest in Nordic walking, their attitude to physical education, self-study exercise.
Постановка проблеми. Фізичне виховання в закладах вищої освіти є невід'ємною складовою частиною формування загальної та професійної культури особистості відповідно до вимог сьогодення, збереження та зміцнення здоров'я, організації та забезпечення здорового способу життя, підвищення рівня працездатності, створення умов для продовження активного творчого довголіття студентства. Нові завдання вищої освіти змушують переглянути деякі положення та концептуальні засади організації фізичного виховання в закладі вищої освіти. Це і визначає, що концептуальними ідеями формування цінностей фізичної культури у студентської молоді в процесі фізичного виховання $\epsilon$ формування гармонійно розвинутої та суспільно активної особистості з високим фізичним, психічним і духовним потенціалом [1].
Зміни цільової спрямованості фізичного виховання, суть якого зводиться до формування фізичної культури особистості, вимагає від навчально-виховного процесу відмови від авторитарних методів, врахування інтересів і потреб студентів у сфері особистого фізичного і духовного вдосконалення. Реалізація даних завдань можлива лише за умови вільного вибору студентами виду рухової активності.

Наукові дослідження і практичний досвід доводять, що обов'язкових двох занять фізичної культури на тиждень замало для позитивних зрушень у стані здоров'я студентів. Необхідно щонайменше вдвічі більше різноманітної рухової активності (спортивні ігри, ходьба, біг, силові види спорту тощо). Але, як свідчать дані статистики, лише п’ята частина студентів додатково 
займаються позанавчальною руховою діяльністю. Отже, постає проблема щодо якомога більше залучити студентів до додаткових занять фізичними вправами і спортом. Для вирішення даної проблеми педагогам варто шукати нові шляхи мотивації студентів до занять фізичною культурою.

Тому в сучасних умовах проводять грунтовні дослідження покращення фізичного виховання в закладах вищої освіти (Н. Боляк [1], Г. Грибан [2], А. Куц [8], А. Цьось [1] та інші). Науковці констатують, що для забезпечення міцного здоров'я студентів необхідно привести їхню рухову активність відповідно до біологічних закономірностей розвитку організму (О. Мозговий, О. Донченко [9], Т. Круцевич [6], Т. Плачинда [10] та інші).

На думку К. Мулик, М. Носко [4] та інших вчених, найбільший оздоровчий ефект відбувається під час використання циклічних засобів аеробного спрямування.

Одним із перспективних шляхів заохочення студентів до систематичних занять фізичною культурою $є$ скандинавська ходьба, оздоровчий вплив якої на серцево-судинну, дихальну та нервову системи організму людини, обмін речовин, загальний стан здоров'я науково доведено [7]. Завдяки всебічному впливу на організм, оздоровчій спрямованості цей вид спорту універсальний не лише для підвищення морфофункціональних якостей, а й поліпшення психоемоційного стану людини. У вітчизняних та зарубіжних наукових працях зі скандинавської ходьби висвітлено питання історії, техніки, програмування навантажень для окремих груп населення [6; 7]. Проте засоби і методи тренування, дозування фізичних навантажень у процесі занять скандинавською ходьбою студентів закладів вищої освіти не були предметом окремого наукового дослідження.

Аналіз літературних джерел дає підстави стверджувати, що скандинавська ходьба має великий потенціал, оскільки може бути представлена в системі навчально-виховного процесу з фізичного виховання як засіб загальної фізичної підготовки студентів, позанавчальної форми організації занять та окремий самостійний спецкурс, що спонукало нас до проведення дослідження.

Мета статті полягає в розкритті ролі і значення скандинавської ходьби в організації самостійних занять студентів як одного із чинників покращення здорового способу життя.

Виклад основного матеріалу дослідження. Ураховуючи матеріальну-технічну базу освітнього закладу та організацію навчально-виховного процесу 3 фізичного виховання, до занять залучались в експериментальних групах студенти, які виявили бажання займатися скандинавською ходьбою. Заняття 3 фізичного виховання, які включали вправи скандинавської ходьби, вирі- шували завдання оздоровлення студентів і формування мотиваційно-ціннісного ставлення та інтересу до занять цим видом рухової активності. Упровадження скандинавської ходьби в навчально-виховний процес із фізичного виховання студентів закладів вищої освіти має проводитися планомірно, системно і послідовно. Під час формування у студентів позитивних уявлень про вплив занять скандинавською ходьбою на їхній організм необхідно на початку навчального року протягом перших двох занять із фізичного виховання поєднати матеріал із техніки безпеки, гігієнічних вимог та теорії фізичної культури і спорту 3 відомостями скандинавської ходьби як ефективного засобу формування організму. Ознайомлення студентів із засобами скандинавської ходьби, які мають використовуватися в процесі проведення навчальних занять із фізичного виховання, здійснюється починаючи із другого заняття. Процес вивчення студентами фізичних вправ, які складають основу занять із скандинавської ходьби, здійснюється на основі таких методичних принципів фізичного виховання, як: принцип від простого до складного, принцип послідовності, принцип усвідомленості, принцип систематичності, принцип доступності, принцип наочності тощо. Заняття 3 фізичного виховання 3 використанням засобів скандинавської ходьби проводилися згідно з розкладом занять двічі на тиждень по 60 хв кожне впродовж навчального року. Теоретичний курс включає систему вихідних параметрів, які покладені в основу розуміння сутності, змісту та структури занять скандинавської ходьби. Практичний курс передбачає навчання техніки виконання вправ із скандинавської ходьби, розвиток фізичних якостей, формування морально-вольових якостей, профілактику травматизму та набуття необхідних умінь і навичок. На першому етапі на заняттях фізичного виховання студенти вивчають комплекс загально-розвиваючих вправ із палками, які використовуються в навчально-тренувальному процесі зі скандинавської ходьби. Під час виконання самостійних завдань студенти вдосконалюють вивчені вправи. На наступних навчальних заняттях із фізичного виховання викладач перевіряє в студентів рівень сформованості навичок щодо виконання спеціальних фізичних вправ та уміння демонструвати їх перед одногрупниками. Студенти, які найкраще оволоділи вправами, проводять зі своїми товаришами підготовчу частину 3 використанням засобів скандинавської ходьби. У подальшому такі цикли повторюються поетапно у відповідності з послідовністю вивчення техніки ходьби. Теоретична підготовка студентів здійснювалася у процесі практичних занять у формі бесід, пояснення, розповіді та перегляду відеозаписів із подальшим аналізом основних елементів та осо- 
бливостей техніки, а також оцінюванням умінь і навиків проведення самостійних занять скандинавською ходьбою. Для якісного засвоєння студентами навчального матеріалу, який вивчався на заняттях, а також для формування умінь самостійного проведення занять студенти розробляли нескладні за змістом комплекси фізичних вправ і використовувати їх для занять зі скандинавської ходьби. При цьому студенти розподілялися на підгрупи, і кожний студент мав можливість провести заняття 3 поставленими завданнями. Навантаження, яке отримував студент під час проведення занять зі скандинавської ходьби, дозувалось 3 урахуванням індивідуальних можливостей кожного студента, його маси тіла та визначалось характером вправ (від найпростіших вправ - локальних до більш складнотехнічних - глобальних), часом проходження дистанції (за сумою кілометрів та за складністю маршруту). Плануючи навантаження, важливо враховувати індивідуальні можливості кожного студента. Не всі відразу можуть опанувати техніку ходьби і дотримуватися необхідного тренувального темпу. У такому випадку вправи виконуються під контролем викладача. Надалі 3 підвищенням фізичної тренованості кількість проходження кілометрів поступово збільшується, а маршрут ускладнюється.

Ставлення студентів до фізичного виховання та, зокрема, до занять скандинавською ходьбою вивчалося за допомогою анкетного опитування. Встановлено, що переважна більшість студентів, $73 \%$, пов'язують здоровий спосіб життя 3 регулярними заняттями фізичними вправами, в той час як до експерименту лише $30 \%$ дотримувалися такої точки зору.

Отримані дані свідчить про усвідомлення студентами ролі і значення занять фізичними вправами в покращенні рівня власного здоров'я. Після формувального експерименту кількість студентів, які систематично виконують ранкову гігієнічну гімнастику, збільшилась на 55\%, зросла кількість студентів, які виконують настанови викладача 3 фізичного виховання в позанавчальний час.

Аналіз матеріалів проведеного дослідження свідчить також про те, що після впровадження в навчально-виховний процес із фізичного виховання засобів скандинавської ходьби у студентів покращилось ставлення до занять 3 фізичного виховання. Встановлено, що кількість студентів, яким подобаються заняття з фізичного виховання, становить $80 \%$, що на $19 \%$ більше в порівнянні 3 результатами, які були отримані до впровадження скандинавської ходьби. Варто відмітити, що наприкінці експерименту збільшилась також кількість студентів, які хотіли б, щоб на заняттях із фізичного виховання використовувались засоби скандинавської ходьби. Так, якщо до впровадження скандинавської ходьби загальна кількість таких студентів не перевищувала 57\%, то після впровадження пауерліфтингу таких студентів було вже 87\%. Встановлено, що наприкінці формувального експерименту кількість студентів, які усвідомлюють, що виконання вправ зі скандинавської ходьби позитивно впливає на їхній організм, збільшилась на $38 \%$, а кількість студентів, які хотіли б навчитися самостійно складати маршрут для занять скандинавською ходьбою та самостійно їх проводити, зросла, відповідно, на $27 \%$ тамна $47 \%$.

Висновки. Результати дослідження засвідчили, що скандинавська ходьба за своєю фізіологічною дією на організм належить до ефективних циклічних вправ аеробного спрямування і може використовуватись як для збільшення обсягу рухової активності, так і для корекції чинників ризику розвитку серцево-судинних захворювань, поліпшення функції дихання і кровообігу, опорно-рухового апарату, обміну речовин. Доведено, що впровадження скандинавської ходьби в навчально-виховний процес із фізичного виховання позитивно впливає на формування у студентів мотивації та інтересу до занять скандинавською ходьбою, ставлення їх до занять із фізичного виховання, самостійних занять фізичними вправами.

Перспективами подальших досліджень уважаємо здійснення комплексної оцінки рівня сформованості знань та практичних навичок студентів щодо використання скандинавської ходьби у процесі проведення самостійних навчально-тренувальних занять.

\section{ЛІТЕРАТУРА}

1. Боляк Н. Сучасні підходи до проблеми вдосконалення процесу фізичного виховання студентської молоді. Слобожанський науково-спортивний вісник. Харків : ХДАФК, 2009. № 2. С. 22-25.

2. Грибан Г. Особливості фізичної підготовленості студентів вищих навчальних закладів України. Bicник Чернігівського начіонального педагогічного університету. Серія «Педагогічні науки. Фізичне виховання та спорт». 2014. Вип. 118. С. 88-93.

3. Гринько В. Ставлення студентів до фізичного виховання і здорового способу життя та їх самооцінка рівня фізичної підготовленості. Слобожанський науково-спортивний вісник. Харків : ХДАФК, 2015. № 1(45). C. 55-59.

4. Мулик К.В., Носко М.О. Диференційований підхід до підготовки фахівців зі спортивно-оздоровчого туризму для роботи 3 дітьми, підлітками та студентською молоддю. Вісник Чернігівського начіонального педагогічного університету. Серія: Педагогічні науки. Фізичне виховання та спорт. 2015. Вип. 129(2). С. 217-222. 
5. Мунтян В. Мотиваційно-ціннісне ставлення студентів до навчання, фізичного виховання і здорового способу життя. Науковий часопис Національного педагогічного університету імені М.П. Драгоманова. Серія 15. Київ : Вид-во НПУ імені М.П. Драгоманова, 2014. № 3(45). С. 182-188.

6. Круцевич Т., Малахова Ж. Фізична підготовленість студентів у сучасних умовах навчання в медичних закладах вищої освіти. Спортивний вісник Придніпров'я. Дніпро : Інновація. 2018. № 2. С. 65-68.

7. Касарда О.З. Розвиток рухової активності студенток вищих навчальних закладів у процесі занять скандинавською ходьбою : дис. ... канд. пед. наук : 13.00.02. Луцьк, 2016. 198 с.

8. Куц А. Модельные показатели физического развития и физической подготовленности детей Центральной Украины. Киев : Искра, 1994. 253 с.

9. Мозговий О., Донченко I. Загальна характеристика здоров’я студентів ВНЗ. Вісник Запорізького наиіонального університету : збірник наукових статей. Фізичне виховання та спорт. Запоріжжя : Запорізький національний університет, 2012. № 2(8). С. 92-97.

10. Плачинда Т. Ставлення студентів до фізичної культури і спорту у процесі їх фізичного виховання. Психолого-педагогічні проблеми сільської школи. 2007. № 23. С. 38-42.

11. Цьось А.В., Шевчук А.Б., Самчук О.М., Хомич А.В., Касарда О.З. Особливості фізичної активності студенток вищих навчальних закладів. Вісник Чернігівського начіонального педагогічного університету. Серія : «Педагогічні науки. Фізичне виховання та спорт». 2015. Вип. 129, т. III. С. 329-334.

\section{REFERENCES}

1. Boliak N.L. (2009). Suchasni pidkhody do problemy vdoskonalennia protsesu fizychnoho vykhovannia studentskoi molodi [Modern approaches to the problem of improving the process of physical education of student youth]. Slobozhanskyi naukovo-sportyvnyi visnyk. Kh. № 2. S. 22-25. [in Ukrainian].

2. Hryban H.P. (2014). Osoblyvosti fizychnoi pidhotovlenosti studentiv vyshchykh navchalnykh zakladiv Ukrainy [Features of physical fitness of students of higher educational institutions of Ukraine]. Visnyk Chernihivskoho natsionalnoho pedahohichnoho universytetu im. T.H. Shevchenka: zb. nauk. pr. Chernihiv: ChNPU. Vyp. 118. S. 88-93. [in Ukrainian].

3. Hrynko V.M. (2015). Stavlennia studentiv do fizychnoho vykhovannia i zdorovoho sposobu zhyttia ta yikh samootsinka rivnia fizychnoi pidhotovlenosti [Attitudes of students to physical education and a healthy lifestyle and their self-assessment of physical fitness]. Slobozhanskyi naukovo-sportyvnyi visnyk. Kharkiv: KhDAFK. № 1 (45). S. 55-59. [in Ukrainian].

4. Mulyk K.V., Nosko M.O. (2015). Dyferentsiiovanyi pidkhid do pidhotovky fakhivtsiv zi sportyvno-ozdorovchoho turyzmu dlia roboty z ditmy, pidlitkamy ta studentskoiu moloddiu [Differentiated approach to the training of specialists in sports and health tourism to work with children, adolescents and students]. Bulletin of Chernihiv National Pedagogical University. Series: Pedagogical sciences. Physical education and sports. № 129 (2). P. 217-222. [in Ukrainian].

5. Muntian V.S. (2014). Motyvatsiino-tsinnisne stavlennia studentiv do navchannia, fizychnoho vykhovannia i zdorovoho sposobu zhyttia [Motivational and value attitude of students to education, physical education and a healthy lifestyle]. Naukovo-pedahohichni problemy fizychnoi kultury. K. : v-vo NPU im. M.P. Drahomanova. Vypusk 3 K (45) ю S. 182-188. [in Ukrainian].

6. Krutsevych T., Malakhova Z. (2018). Fizychna pidhotovlenistj studentiv u suchasnykh umovakh navchannja v medychnykh zakladakh vyshchoji osvity [Physical training of students in the current conditions of education at higher medical education institutions]. Sportyvnyi visnyk Prydniprovia. №2. P. 65-68. [in Ukrainian].

7. Kasarda O.Z. (2016). Development of motor activity of female students of higher educational institutions in the process of Scandinavian walking: dis. ... cand. ped. science: 13.00.02. Lutsk, 2016. 1998 p. [in Ukrainian].

8. Kuts A.S. (1994). Modelnyie pokazateli fizicheskogo razvitiya i fizicheskoy podgotovlennosti detey Tsentralnoy Ukrainyi [Model indicators of physical development and physical fitness of children in Central Ukraine]. K. : Iskra. 253 s. [in Ukrainian].

9. Mozgoviy O.I, Donchenko I.S. (2012). Zagalna harakteristika zdorov'ya studentIv VNZ [General characteristics of the health of university students]. VIsnik ZaporIzkogo natsIonalnogo unIversitetu. № 2 (8). S. 92-97. [in Ukrainian].

10. Plachynda T. (2007). Stavlennia studentiv do fizychnoi kultury i sportu u protsesi yikh fizychnoho vykhovannia [Attitudes of students to physical culture and sports in the process of their physical education]. Psykholoho-pedahohichni problemy silskoi shkoly. № 23. S. 38-42. [in Ukrainian].

11. Tsyos A.V., Shevchuk A.B., Samchuk O.M., Khomich A.V., Kasarda O.Z. (2015). Features of physical activity of students of higher educational institutions. Bulletin of Chernihiv National Pedagogical University. Series: «Pedagogical sciences. Physical education and sports». 2015. Vip. 129, vol. III. P. 329-334. 